\title{
The Sections Apostemium and Microstemium of the Genus Vibrissea (Fungi) ${ }^{1}$
}

\author{
Apolinar Sánchez ${ }^{2}$
}

\section{INTRODUCTION}

The genus Vibrissea, consisting of aquatic or semiaquatic inoperculate discomycetes with long, filiform ascospores, has recently been divided into four sections by Sánchez and Korf $(9)^{3}$, who have also discussed the competing generic names Leptosporium, Apostemium, Apostemidium, Gorgoniceps, and Ophiogloea. The materials and methods outlined in that paper were those employed here. This report consists of a detailed nomenclatural and taxonomic study of the species assigned to two of the sections which include nearly all of the sessile species of the genus.

\section{KEY TO THE SPECIES OF THE SECTIONS APOSTEMIUM AND MICROSTEMIUM ${ }^{4}$}

A. Apothecia substipitate or sessile, $0.7-3 \mathrm{~mm}$. in diam. $\times 0.4-2.5 \mathrm{~mm}$. high; asci $6-8(-10) \mu$ wide; spores $100-470 \times 1-2 \mu \ldots \ldots \ldots \ldots \ldots$ Section Apostemium

${ }^{1}$ Based on a thesis presented to the Graduate School of Cornell University, in partial completion of the requirements for the Master of Science degree, September 1965. Supported by funds from the Agricultural Experiment Station of the University of Puerto Rico, Río Piedras, P.R., and by The National Science Foundation grant GB-2339, Monographic Studies of the Discomycetes, Richard P. Korf, Principal Investigator.

${ }^{2}$ Former Research Assistant, Agricultural Experiment Station, University of Puerto Rico, Río Piedras, P.R. Present address: Senior Curator, Plant Pathology Herbarium, Cornell University, Ithaca, N. Y. 14850. The author wishes to express his thanks to Prof. William J. Dress, Bailey Hortorium, Cornell University, for providing the Latin diagnoses. Thanks are also due to the following persons for sending herbarium specimens: Dr. W. D. Graddon, Llangrove, Ross-on-Wye, Herefordshire, England; Dr. J. Gremmen, Forest Research Station T.N.O., Wageningen, Netherlands; Dr. J. C. F. Hopkins, Director, Commonwealth Mycological Institute, Kew, Surrey, England; Dr. A. Kalela, Director, Botanical Museum, University of Helsinki, Helsinki, Finland; Dr. I. Mackenzie Lamb, Director, Farlow Library and Herbarium, Harvard University, Cambridge, Mass.; Prof. J. A. Nannfeldt, Director, The Botanical Museum, University of Uppsala, Uppsala, Sweden; Dr. A. Pilát, Director, Botanical Department of the National Museum, Prague, Czechoslovakia; Prof. Dr. K. H. Rechinger, Director, Naturhistorisches Museum, Wien, Austria; Dr. A. H. Smith, Director, University Herbarium, University of Michigan, Ann Arbor, Mich.; and Sir George Taylor, Director, The Herbarium and Library, Royal Botanic Gardens, Kew, Surrey, England.

${ }^{3}$ Italic numbers in parentheses refer to Literature Cited, pp. 92-3.

${ }^{4}$ Spore lengths are based on whole spores measured in the ascus. Since spores may disarticulate in the ascus or on discharge in some species, care must be taken not to measure part-spores. 
B. Apothecia substipitate (hymenium making up $1 / 3$ to $1 / 6$ of the total height of the apothecium); asci 6-7 $\mu$ wide, ascus stalk 50-70 $\mu$ long; ascus pore $\mathrm{J}-$; receptacle and base dark; disk yellow or grey

B. Apothecia sessile (hymenium making up 40 percent or more of the total height of the apothecium); asci 6-8 (-10) $\mu$ wide, ascus stalk 5-30 $\mu$ long; ascus pore $\mathrm{J}+$ or $\mathrm{J}-$; receptacle and base brown or

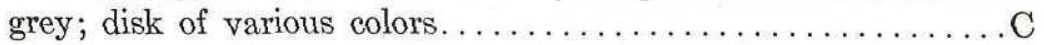

C. Ascus pore J+; paraphyses simple, rarely branched at their free ends, apices 4-6 $\mu$ wide; outermost cells of the ectal excipulum often continuing to grow into hairlike or beadlike projections; disk yellow, greyish, black or orange...Vibrissea decolorans

C. Ascus pore J-; paraphyses several times branched, often fasciculately so, rarely simple, apices $2-5 \mu$ wide; outermost cells of the ectal excipulum round or pyriform, without projections; disk bluish-grey, yellow or ochraceous..... Vibrissea filisporia D. Spores over $400 \mu$ long; asci 8-10 $\mu$ wide; ectal excipulum over $100 \mu$ thick............ filisporia f. gigantospora

D. Spores less than $315 \mu$ long; asci 6-7 (-8) $\mu$ wide; ectal excipulum $30-90(-126) \mu$ thick................. E. Spores 210-290 (-315) $\mu$ long; ectal excipulum (64-) 72-90 (-126) $\mu$ thick; paraphyses once to several times branched, often fasciculately so..V. filisporia f. boudieri E. Spores 100-210 $\mu$ long; ectal excipulum 30-76 $\mu$ thick. .F F. Paraphysis apices simple...V. filisporia f. fiscella

F. Paraphysis apices branched. .V. filisporia f. filisporia A. Apothecia sessile, minute, $0.2-0.5 \mathrm{~mm}$. in diam. $\times 0.15-0.26 \mathrm{~mm}$. high, or bigger, $1.5 \times 0.5 \mathrm{~mm}$; asci $11-12 \mu$ wide; spores $85-175 \times$ $3-3.5 \mu \ldots \ldots \ldots \ldots \ldots \ldots \ldots \ldots \ldots \ldots \ldots \ldots \ldots \ldots$ Section Microstemium

B. Spores 145-175 $\mu$ long; paraphyses once to several times branched, some simple, apices 4-5 $\mu$ wide; epithecium present; receptacle furfuraceous; perihymenial zone blued by iodine.............

Vibrissea sporogyra

B. Spores 85-95 $\mu$ long; paraphyses mainly simple, some branched, apices 2-2.5 $\mu$ wide; epithecium absent; receptacle smooth; perihymenial zone not blued by iodine......... Vibrissea norvegica

\section{DESCRIPTIONS OF ACCEPTED SPECIES}

1. Vibrissea pezizoides Lib. ex Phillips, Trans. Linn. Soc. II 2: 8, 1881. = Apostemidium torrenticola Gradd., Trans. Brit. Mycol. Soc. 48: 643, 1965. 
Apothecia substipitate (the hymenium averaging 1/3 to $1 / 6$ of the total height of the apothecium), 1.5 to $3 \mathrm{~mm}$. in diameter; disk yellow or very rarely bluish-grey; receptacle black or rarely brown, often crenulate; asci 200 to $300 \times 6$ to $7 \mu$, ascus pore $J$-, ascus stalk 50 to $70 \mu$ long; ascospores 160 to $230 \times 1$ to $2 \mu$, often disarticulating in the middle inside the ascus and liberated from the ascus as such (fig. 1,G); paraphyses about half simple, the other half branched (rarely all simple or all branched), apices slightly enlarged, clavate or obpyriform, 2 to $4(-5) \mu$ wide (fig. 1,A); epithecium 14 to $20 \mu$ thick; ectal excipulum 108 to $144 \mu$ thick, in most cases the

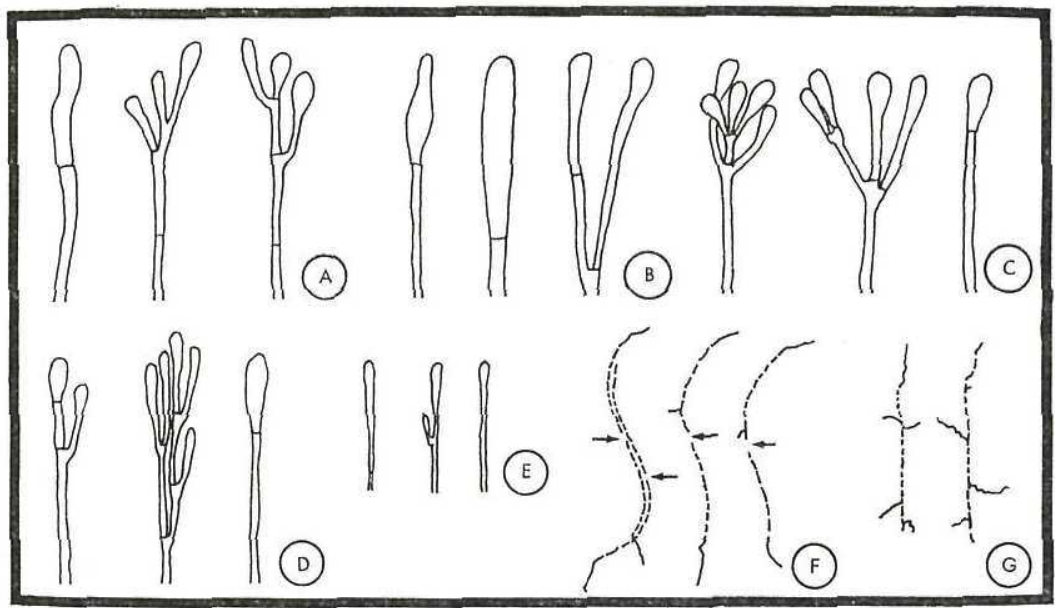

FIG. 1.-Apices of paraphyses and germinating spores of species of Vibrissea: A, V. (Apostemium) pezizoides; B, V. (A.) decolorans; C, V. (A.) filisporia f. boudieri; D, V. (Microstemium) sporogyra; E, V. (M.) norvegica; F, V. (A.) filisporia f. boudieri; $\mathrm{G}, V$. (A.) pezizoides. Paraphyses drawn with the aid of a camera lucida at $\times 1000$ and reproduced at $\times 500$. Germinating spores traced from photographs; points of disarticulation indicated by arrows; $\mathrm{F}, \times 95, \mathrm{G}, \times 87$.

inner cells becoming wine-red in iodine; the medullary excipulum bluing faintly in iodine, rarely not bluing.

habitat: On Quercus, Betula, Picea, etc., in or near streams.

Name: From its resemblance to Peziza, i.e., discoid rather than stipitate. TYPE LOCALITY: Unknown.

TYPE SPECIMEN: Royal Botanic Gardens, Kew.

ILlustrations: Phillips, Trans. Linn. Soc. II 2: pl. 2, f. 8-13, 1881; Velenovský, Mon. Disc. Boh. 2: pl. 31, f. 22, 1934; Graddon, Trans. Brit. Mycol. Soc. 48: f.1, D(d), E, 1965; Sánchez \& Korf, Mycologia 58: (in press) f. 1-2, 1966. exsiccati: None. 
SPECIMENS EXAMINED:

Czechoslovakia

Cejp, on wood in a stream, Mt. Boubin, August 1928 (PR 154051) (CUP 48829).

\section{Great Britain}

Durand, on dead Thorn wood in spray of fall, Hebden Bridge, 3 August 1904 (CUP-D 274)5 ; Graddon, on Quercus sp. near a stream, Kirkcaldy, June 1962, HOLOTYPE of Apostemidium torrenticola, (Graddon No. 1613) (CUP 48828).

\section{Japan}

Imai, et al., on wood immersed in swift stream, near Lake Shikotsu, Hokkaido, 20 May 1958 (CUP-F.J. 743); another collection, (CUP-F.J. 757); Imai, et al., on wood of Betula and Picea in a stream near Daisetsuzan Natl. Park, Ishikari Prov., Hokkaido, 24 May 1958 (CUP-F.J. 796); Imai, et al., on twigs in water near Lake Akan, Kushiro Prov., Hokkaido, 28 May 1958 (CUP-F.J. 866).

North America

Rogers, et al., on partly submerged log, Lloyd-Cornell Preserve McLean, New York, 17 June 1964 (CUP 48099); Sánchez, on wet decorticated branches lying in a semidry stream, Alpine, New York, 24 June 1964 (CUP 48100); Sánchez, on twig in a wet shady place near a semidry stream, Alpine, New York, 24 June 1964 (CUP 48101); Sheldon, (no substrate) Delleslow, Monongalia Co., West Virginia, 28 May 1907 (CUP 48108).

\section{Locality Unknown}

Mme. Libert, (no substrate) (no locality) (no date), HOLOTYPE of $V i$ brissea pezizoides (K) (CUP 48117).

\section{NOTES:}

$V$. pezizoides differs from $V$. decolorans in that its apothecia have a stalklike base, the asci have long sterile stalks 50 to $70 \mu$ long, the ascus pore does not blue in iodine, and the ascospores are straight and disarticulate inside the ascus.

The closely related $V$. filisporia lacks a stalk, and has paraphyses repeatedly branched; the receptacle is brown, the spores sigmoid and the asci have a very short ascus stalk.

${ }^{5}$ Herbarium abbreviations are those of Lanjouw and Stafleu (8), with in some cases, added symbols indicating special collections of those herbaria. 
2. Vibrissea decolorans (Saut.) Sánchez \& Korf, comb. nov.

$\equiv$ Helotium (Calycella) decolorans Saut. Mitt. Ges. Salzb. Landesk. 6: 48, (May or earlier) 1866, non Helotium decolorans Vel. Mon. Disc. Boh. 1: 201, 1934.

$\equiv$ Peziza decolorans Saut. Flora 2/: 312, 1841, non P. decolorans

Wallr. Fl. Crypt. Germ., p. 490, 1833, nec P. decolorans B. \& C. Grevillea 3: 150, 1874.

$\equiv$ Gorgoniceps decolorans (Saut.) Sacc. Syll. Fung. 8: 505, 1889.

$\equiv$ Belonopsis decolorans (Saut.) Rehm, in Rabenh. Krypt.-Fl. 1 (3): $572,1891$.

$\equiv$ Apostemidium decolorans (Saut.) Boud., Hist. Classif. Disc. Eur. p. 90, 1907.

$=$ Peziza (Fibrina) leptospora B. \& Br. Ann. Mag. Nat. Hist. III 18: 126, (August) 1866.

$\equiv$ Vibrissea leptospora (B. \& Br.) Phill. Trans. Linn. Soc. II 2: 8, 1881.

$\equiv$ Gorgoniceps leptospora (B. \& Br.) Sacc. Syll. Fung. 8: 505, 1889.

$\equiv$ Vibrissea guernisacii var. leptospora (B. \& Br.) Mass. Brit. Fung.-Flora 4: 488, 1895. ["Guernisaci"]

$\equiv$ Apostemidium leptosporum (B. \& Br.) Boud. Hist. Classif. Disc. Eur. p. 91, 1907. ["Teptospora"]

$=$ Patellaria fergussonii B. \& Br. Ann. Mag. Nat. Hist. IV 15: 39, 1875. ["Fergussoni"]

$\equiv$ Vibrissea fergussonii (B. \& Br.) Phill. Trans. Linn. Soc. II 2: 7, 1881. ["Fergussoni"]

$=$ Helotium vibrisseoides Peck, Ann. Rept. N.Y. State Mus. 32: 48, 1878.

$\equiv$ Vibrissea turbinata Phill., Trans. Linn. Soc. II 2: 8, 1881. [nom. superfl.] [V. "turbinulata" Phill. in Ell. \& Ev. N. Am. F., 2738.]

$\equiv$ Gorgoniceps turbinata (Phill.) Sacc. Bot. Centr. 18: 219, 1884.

$\equiv$ Gorgoniceps vibrisseoides (Pk.) Sacc. Syll. Fung. 8: 505, 1889.

$\equiv$ Vibrissea guernisacii var. vibrisseoides (Pk.) Mass. Brit. Fung.Fl. 4: 488, 1895. ["Guernisaci"]

$\equiv$ A postemidium vibrisseoides (Pk.) Boud. in Lagarde, Ann. Mycol. 4: 240, 1906. ["vibrissoides"]

$\equiv$ Vibrissea vibrisseoides (Pk.) Kjøller, Bot. Tidssk. 56: 242, 1960.

= Vibrissea crenulata Vel. Mon. Disc. Boh. 1: 382, 1934.

$=$ Vibrissea pezizoides var. montana Vel. Mon. Disc. Boh. 1: 382, 1934.

=? Ophiogloea linospora Clem. Bull. Torr. Bot. Club 30: 87, 1903.

Apothecia sessile (the hymenium averaging 40 to 80 percent of the total 
height of the apothecium), 1 to $3 \mathrm{~mm}$. in diameter; disk bluish-grey or yellow, rarely dark or orange; receptable brown to dark brown; asci 270 to $360 \times 7$ to $8 \mu$, ascus pore $J+$, ascus stalk 10 to $25 \mu$ long; ascospores 250 to $350 \times 1$ to $2 \mu$, not observed to disarticulate inside the ascus ${ }^{6}$; paraphyses simple, rarely branched once or twice dichotomously, apices obpyriform to clavate, 4 to $6 \mu$ wide (fig. 1,B); epithecium absent or if present 7 to $20 \mu$ thick; ectal excipulum 80 to $140 \mu$ thick, the outermost cells often continuing to grow into 3, 4 or more hair-like or monilioid, brown to dark brown cells; the medullary excipulum, in most cases, bright blue in iodine, rarely not reacting. No wine red in iodine was observed in the specimens studied.

habitat: On Carpinus, Rubus, Prunus, etc., submerged in water. NAME: From Latin decolor $=$ discolored.

TYPE LOCALITY: Salzburg, Austria.

TYPE SPECIMEN: Naturhistorisches Museum, Wien.

inlustrations: Berkeley \& Broome, Ann. Mag. Nat. Hist. III 18: pl. 4, f. 30, 1866; ibid. IV 15: pl. 2, f. 6 a-d, 1875; Phillips, Trans. Linn. Soc. II 2: pl. 2, f. 14-23 (in error), 1881; Peck, Bull. N.Y. State Mus. 1(2): pl. 2, f. 7-9, 1887; Durand, Ann. Mycol. 6: pl. 11, f. 119, 120, 1908; Velenovský, Mon. Disc. Boh. 2: pl. 31, f. 16, 17, 1934; Overholts, Mycologia 32: 257, f. 3, 1940; Kjøller, Bot. Tidssk. 56: 243, f. 1, a-d, 1960;

Graddon, Trans. Brit. Mycol. Soc. 48: 639, f. 1, D(e, f), 2, A, B, 1965;

Sánchez \& Korf, Mycologia 58: (in press) f. 2, 1966.

Exsiccati: None.

SPECIMENS EXAMINED:

Austria

Sauter, (no substrate) (no locality) (no date) AUTHENTIC and probably HOLOTYPE of Peziza decolorans (W) (CUP 48123).

\section{Czechoslovakia}

Velenovský, on Carpinus sp. in a swamp near Mnichovo, September 1924, LECTOTYPE of Vibrissea crenulata (PR 147866); Pilát, on Rubus idaeus near Mt. Sudeten, September 1923, AUTHENTIC, probably HOLOTYPE of Vibrissea pezizoides var. montana (PR 148619).

\section{Great Britain}

Berkeley and Broome, on Prunus padus, New Pitsligo, 1874, HOLOTYPE of Patellaria Fergussoni, (K) (CUP 48121); Durand, on wood in

${ }^{6}$ Kjøller (6) has reported that the spores of Vibrissea vibrisseoides (Pk.) Kjøller often disarticulate inside the ascus. 
stream, Hebden Bridge, 3 August 1904 (CUP-D 273); Jerdon, (no substrate) Jedburgh (no date) HOLOTYPE of Peziza leptospora, (K) (CUP 48122); Needham, on Thorn wood in stream, Hebden Valley, 22 April 1892 (CUP-D 271).

\section{Japan}

Ozoe, et al., on water-soaked branchlets in a stream, Daisen Natl. Park, Tottori Pref., Honshu, 18 April 1958 (CUP-F.J. 521).

North America

Cain, on decaying sticks in small stream, Bear Island, Ontario, Canada, 16 June 1933 (CUP 24692); Kimbrough \& Korf, on twig 8 in. under water in a stream, Hendershot, Alpine, N.Y., 29 April 1963 (CUP 47394); Moore \& Korf, on twig in water, Hendershot, Alpine, N.Y., 6 June 1962 (CUP 46209); Peck, on dead wood in a stream, Sandlake, N.Y., May 1878, ISO-SYNTYPE of Helotium vibrisseoides (CUP-D 3021); Peck, on dead wood in a stream, Catskill Mts., N.Y., (no date) ISO-SYNTYPE of Helotium vibrisseoides (CUP-D 5414).

\section{NOTES:}

The name Peziza decolorans Sauter (10) is a later homonym of $P$. decolorans Wallr. Sauter (11) later transferred the species to the genus Helotium, where the epithet was apparently not preoccupied. According to the International Code of Botanical Nomenclature (7), Art. 72, the name Helotium decolorans must be treated as a new name. Peziza leptospora Berk. \& Br. (1) was published in the same year as $H$. decolorans, but appeared at least after July 23, 1866 (see Ann. Mag. Nat. Hist. III 18: 137, 1866). $H$. decolorans appeared in an article which was reviewed in Bot. Zeit. 24(19): 150 in the issue of May 11, 1866. Thus it seems clear that the oldest valid name is Helotium decolorans.

3. Vibrissea filisporia (Bon.) Korf \& Sánchez, comb. nov.

$\equiv$ Sarea filisporia Bon. Bot. Zeit. 11: 293, 1853.

Apothecia sessile (hymenium averaging 40 to 80 percent of the total height of the apothecium), 0.7 to $2 \mathrm{~mm}$. in diam.; disk bluish-grey to yellow ochraceous; receptacle brown to light brown; asci 120 to $305(-325) \times$ 6 to $8 \mu$ or rarely 470 to $490 \times 8$ to $10 \mu$, ascus pore $J$-, ascus stalk 5 to $30 \mu$ long; ascospores 100 to $290(-315)$ or rarely 440 to $465 \times 1$ to $2 \mu$; paraphyses once to several times branched, often fasciculate or very rarely simple, apices obpyriform or clavate, rarely slightly enlarged, 2 to $5 \mu$ wide; epithecium 12 to $25(-40) \mu$ thick; ectal excipulum 30 to $108(-126)$ $\mu$ thick, not becoming wine red in iodine; medullary excipulum bluing in iodine, rarely not bluing. 
3 a. VIBRISSEA FILISPORIA forma filisporia

$\equiv$ Sarea filisporia Bon. Bot. Zeit. 11: 293, 1853.

$\equiv$ Leptosporium tremellinum Bon. Bot. Zeit. 15: 211, 1857. [epithet. superfl.]

$\equiv$ Gorgoniceps tremellina (Bon.) Sacc. \& Trav. in Sacc., Syll. Fung. 19: 793, 1910.

$=$ Vibrissea guernisacii Crouan \& Crouan, Ann. Sci. Nat. IV 7: 176, 1857. ["Guernisaci”]

$\equiv$ Gorgoniceps guernisacii (Crouan \& Crouan) Karst. Meddel.

Soc. Fauna Flora Fenn. 9: 55, 1883. ["Guernisaci"]

$\equiv$ Apostemidium guernisacii (Crouan \& Crouan) Boud. Hist.

Classif. Disc. Eur. p. 90, 1907. ["Guernisaci”]

$\equiv$ Godronia guernisacii (Crouan \& Crouan) Kirscht. Ann. Mycol. 38: 225, 1935. [“Guernisaci”]

= Vibrissea media Vel. Mon. Disc. Boh. 1: 383, 1934.

= Vibrissea minima Vel. Mon. Disc. Boh. 1: 383, 1934.

The type forma has a moderately thin ectal excipulum $(30$ to $76 \mu)$; the paraphyses are branched, intermixed with some simple apices; the medullary excipulum is not or only faintly blued by iodine; the spores are 100 to $210 \mu$ long.

HАВітAт: On Salix spp. in streams.

NAME: From Latin filum $=$ a thread, + spora $=$ a seed.

TYPE LOCALITY: Unknown.

TYPE SPECIMEN: Unknown.

illustrations: Bonorden, Bot. Zeit. 15: pl. 4, f. C (a-g), 1857; Crouan \&

Crouan, Ann. Sci. Nat. IV 7: pl. 4, f. 24-27, 1857; Durand, Ann. Mycol.

6: pl. 11, f. 114, 1908; Nannfeldt, Nova Acta Reg. Soc. Upsal. IV 8(2):

78, f. 3, 1932; Velenovský, Mon. Disc. Boh. 2: pl. 31, f. 18, 19, 1934;

Graddon, Trans. Brit. Mycol. Soc. 48: 640, f. 1, B, D (a), 1965.

exsicCATI: Karsten, F. Fenn. Exs. No. 764 (Peziza fiscella) (CUP-D 3674)

( $\mathrm{FH})$.

SPECIMENS EXAMINED:

\section{Czechoslovakia}

Velenovský, on Salix caprea? in a swamp near Lysá, May 1924, LECTOTYPE of Vibrissea minima (PR 149146); Velenovský, on Salix caprea? in warm water in a swamp near Mnichovo, June 1931, HOLOTYPE of Vibrissea media (PR 153240).

\section{Finland}

Karsten, F. Fenn. Exs. 764 (CUP-D 3674) (FH). 
Netherlands

Daams, on dead twig of Salix sp. in a marsh near Nederwetten, 10 June 1953 (Gremmen No. 669) (CUP 48318).

NOTES:

Though Gremmen (3) recorded a spore length of $90 \mu$ for the specimen from the Netherlands cited above, they were found to be 130 to $155 \mu$ long.

3 b. Vibrissea filisporia forma fiscella (Karst.) Sánchez, comb. nov. $\equiv$ Peziza fiscella Karst. Not. Sällsk. Fauna Flora Fenn. Förh. 10: 154, 1869.

$\equiv$ A postemium fiscella (Karst.) Karst. Not. Sällsk. Fauna Flora Fenn. Förh. 11: 243, 1870.

$\equiv$ A postemidium fiscella (Karst.) Karst. Mycol. Fenn. 1: 186, 1871.

$\equiv$ Gorgoniceps fiscella (Karst.) Sacc. Bot. Centr. 18: 219, 1884.

This forma differs from the type forma primarily in having simple paraphyses. The spores in the specimen examined are 185 to $210 \mu$ long. навітAт: On Alnus incana in a humid place.

NAME: From Latin fiscella $=$ a small basket for fruits.

TYPE LOCALITY: Mustiala.

TYPE SPECIMEN: Botanical Museum, Helsinki.

iLlustrations: None.

EXsicCATi: None (see forma filisporia).

SPECIMEN EXAMINED:

Finland

Karsten, (no substrate) (no locality) (no date) HOLOTYPE of Peziza fiscella $(\mathrm{H})$.

NOTES:

The only specimen of Peziza fiscella Karst. from Karsten's herbarium on deposit in the Botanical Museum at Helsinki is the one cited above. It exhibits the characters given by Karsten. (5) in the original description. Except for its simple paraphyses it is identical to specimen No. 764 in Karsten, Fungi Fenn. Exs., cited erroneously by Graddon (2) as the type of Peziza fiscella.

3 c. Vibrissea filisporia forma boudieri Sánchez \& Korf, forma nov. $\equiv$ Schizoxylon alneum Feltg. Vorst. Pilz-Fl. Grossh. Luxemb. Ascomycetes 1(2): 90, 1901. 
= Vibrissea calcaria Vel. Nov. Mycol. Nov. p. 156, 1947.

$=$ Apostemidium fiscella var. submersum Gradd. Trans. Brit. Mycol. Soc. 48: 643, 1965.

A forma typica differt in sporis longioribus, $210-315 \mu$, et in paraphysibus saepe ramificantibus in extremitatibus liberis in fasciculis ramorum ternorum vel aliquot.

HоLотүрus: Schizoxylon alneum Feltg., Vorst. Pilz-Fl. Grossh. Luxemb. Ascomycetes 1(2): 90, 1901.

This forma is the most widely distributed of the species; the paraphyses are repeatedly branched, often in fascicles of 3 or more (fig. 1,C); the spores are 210 to $315 \mu$ long (fig. $1, \mathrm{~F}$ ); the ectal excipulum is (64-) 72 to $90(-126) \mu$ thick; the asci are 6 to $7(-8) \mu$ wide. The descriptions and illustrations of a large number of specimens, referred in the literature to Vibrissea or Apostemidium guernisacii, match perfectly the characters of $V$. filisporia $\mathrm{f}$. boudieri.

навітат: On dead branches of Salix, Alnus, Rosa and possibly other plants under water, in streams.

NAME: In honor of the French mycologist Emile Boudier, whose interpretation of $V$. guernisacii Cr. \& Cr. has been followed by most later authors.

TYPE LOCALITY: Schimpach., Luxemburg.

type specimen: Farlow Herbarium, Harvard University, Cambridge, Mass.

ILlustrations: Phillips, Trans. Linn. Soc. II 2: pl. 2, f. 1-7 (4 and 6 partially in error), 1881; Phillips, Man. Brit. Disc. pl. 10, f. 61 (b-d partially in error), 1887; ?Patouillard, Tab. Anal. Fung. I, Fasc. IV, f. 369, 1883; Boudier, Icon. Mycol. 3: pl. 433, 1908; Lloyd, Mycol. Writings 5 (The Geoglossaceae): 19, f. 807, 1916-19; Graddon, Trans. Brit. Mycol. Soc. 48: 640, f. 1, D (c), 1965; Sánchez \& Korf, Mycologia 58: (in. press) f. 2, 1966.

ExsicCAtr: Ell. \& Everh. N. Am. F. 2738 (Vibrissea turbinulata) (CUP-A); Jaap, F. Sel. Exs. 808 (Apostemidium guernisacii) (CUP); Phillips, Elv. Brit. 143 (Vibrissea guernisacii) (CUP-D 11145); Rehm, Ascomyceten 1605 (Gorgoniceps fiscella) (CUP-D 11911).

SPECIMENS EXAMINED:

Czechoslovakia

Vacek, on a dead branch in a stream near Karlovy Vary, July 1942, HOLOTYPE of Vibrissea calcaria, (PR 154054).

\section{Germany}

Jaap, unter Wasser an faulenden Weidenzweigen in alten Mergelgruben, Prov. Brandenburg, 18 June 1917, F. Sel. Exs. 808 (CUP); Kirschstein, 
an faulenden Salix-Aestchen am Havel-Ufer bei Rathenow, Brandenburg, June 1905, Rehm, Ascomyceten 1605 (CUP-D 11911).

Great Britain

Phillips, on willow, Shrewsbury, (no date), Elv. Brit. 143 (CUP-D 11145).

\section{Japan}

Imai, et al., on twigs of Salix in a stream, Lake Kutcharo, Kushiro Prov., Hokkaido, 30 May 1958 (CUP-F.J. 921).

\section{Luxemburg}

Feltgen, on Alnus, Schimpach., September 1900, AUTHENTIC, possibly HOLOTYPE of Schizoxylon alneum (FH).

\section{North America}

Parker, on twigs floating in water in a swamp, King County, Washington, August 1892 (CUP-D 4817); Peck, on submerged willow (no locality) (no date) (CUP-D 9091); Sánchez, on twig of Rosa multiflora, in small stream near Buttermilk Park, Ithaca, N.Y., 30 May 1964 (CUP 48097); Sánchez, another collection (CUP 48098); Sheldon, on twigs of rose in a brook, Central Village, Connecticut, 17 August 1908 (CUP-D 6488); Thaxter, on wood in rapid water, Milford, Connecticut, June 1891 (CUP-D 2480); Thaxter, on dead branches lying in a ditch, New Haven, Connecticut, May 1889, Ell. \& Everh. N. Am. F. 2738 (CUP-A); Thaxter, on branches in a ditch, West Haven, Connecticut, May 1889 (CUP-D 2478); Thaxter, on wood in a brook, York, Maine, 11 July 1893 (CUP-D 2481).

\section{Sweden}

Nannfeldt, on a submerged branch in a rivulet near Gävle, 27 June 1950 HOLOTYPE of Apostemidium fiscella var. submersum, (UPS 10843) (Personal herbarium of W. D. Graddon) (CUP 48822).

3 d. Vibrissea Filisporia forma gigantospora Sánchez, forma nov.

A forma typica in ascis $470-490 \times 8-10 \mu$, sporis $440-465 \times 1-2 \mu$ differt.

Holotypus: CUP-D 2704.

This forma is rather rare; the apothecia are 1 to $2 \mathrm{~mm}$. in diam.; the disk is yellow; the asci, 470 to $490 \times 8$ to $10 \mu$ and the spores, 440 to $465 \times$ 1 to $2 \mu$ are the largest found so far in section Apostemium.

НАВітAт: On a dead twig in a river.

NAME: From Latin gigas $=$ giant + spora $=$ a seed .

TYPE LOCALITY: Washington. 
Type specimen: Plant Pathology Herbarium, Cornell University, Ithaca, N.Y.

illustration: Ingold, Trans. Brit. Mycol. Soc. 37: 4, 5, f. 3, 4, 1954. EXsicCATi: None.

SPECIMEN EXAMINED:

North America

Parker, on dead twig in river, King County, Washington, March 1891 (CUP-D 2704).

NOTES:

Ingold (4) has described and illustrated a specimen from England which apparently belongs to this forma. The asci in that specimen are reported to be 360 to $425 \times 7.5$ to $9 \mu$. Since Ingold admits that he did not see septa in the spores one might suspect that his specimen is somewhat immature.

4. Vibrissea sporogyra (Ingold) Sánchez in Sánchez \& Korf, Mycologia 58: (in press). 1966.

$\equiv$ A postemidium sporogyrum Ingold, Trans. Brit. Mycol. Soc. 37: 13, 1954.

Apothecia sessile (hymenium averaging approximately 80 percent of the total height of the apothecium), gregarious, 0.2 to $0.5 \mathrm{~mm}$. in diam. $\times 0.26$ $\mathrm{mm}$. high, separating from the substrate, when dry, with the entire subiculum remaining attached to it; disk bluish-grey, flat or slightly convex, marginate; receptacle dark brown, furfuraceous; asci broad, cylindrical, 150 to 180 (Ingold: 170 to 200$) \times 12 \mu$, ascus pore $J+$, ascus stalk $5 \mu$ long; ascospores 145 to 175 (Ingold: 125 to 160$) \times 3 \mu$, twisted spirally together, filling the entire ascus length; paraphyses once to several times branched at their free end, apices obpyriform or clavate, 4 to $5 \mu$ wide (fig. $1, \mathrm{D}$ ); epithecium very inconspicuous, $5 \mu$ thick; ectal excipulum approximately $36 \mu$ thick, not becoming wine red in iodine; medullary excipulum very reduced, not blued by iodine; perihymenial zone blued by iodine.

HABITAT: On dead stalks and leaves of Carex rostrata, Eleocharis palustris and Equisetum fluviatile, in lakes.

NAME: From Latin spora $=$ a seed + gyrus $=$ spiral .

TYPE LOCALiTY: Little Langdale, Laneashire, England.

TYPE SPECIMEN: Herbarium IMI 51537.

iLlustrations: Ingold, Trans. Brit. Mycol. Soc. 37: 15, f. 14, 1954; Sánchez

\& Korf, Mycologia 58: (in press), f. 2, 1966.

EXsicCati: None. 


\section{Great Britain}

Ingold, on Carex rostrata, Little Langdale, 1951, HOLOTYPE of Apostemidium sporogyrum Ingold (IMI 51537) (CUP 48115).

5. Vibrissea norvegica (Gremmen) Sánchez, comb. nov.

$\equiv$ A postemidium norvegicum Gremm. Nytt Mag. Botan. 6: 12, 1958.

Apothecia sessile (the hymenium averaging approximately 75 percent of the total height of the apothecium), 0.3 to $0.4 \mathrm{~mm}$. in diam. $\times 0.15 \mathrm{~mm}$. high, strongly attached to the surface of the substrate; disk bluish-grey, marginate; receptable dark brown, not furfuraceous; asci 90 to 100 (Gremmen: 80 to 100$) \times 12 \mu$, ascus pore $J+$, ascus stalk $5 \mu$ long; ascospores 85 to 95 (Gremmen: 75 to 100$) \times 3$ to $3.5 \mu$; paraphyses mainly simple, some once branched, slightly enlarged at their apices which are 2 to $2.5 \mu$ wide (fig. 1,E); epithecium absent; ectal excipulum approximately $25 \mu$ thick, not becoming wine red in iodine; medullary excipulum reduced to a few hyphae, not blued by iodine; perihymenial zone not blued by iodine.

HaBitat: On Phragmites communis in lakes.

NAME: After the locality.

TYPE LOCALITY: Brunkeberg, Telemark, Norway.

TYPE sPeCimen: J. Gremmen's personal herbarium No. 1296, Wageningen, Nederland (CUP 48116).

illustrations: Gremmen, Nytt Mag. Botan. 6: 12, f. 1, 1958; Sánchez \& Korf, Mycologia 58: (in press), f. 2, 1966.

Exsiccati: None.

SPECIMEN EXAMINED:

\section{Norway}

Gremmen, on Phragmites communis, near Brunkeberg, Telemark, 20 August 1956, HOLOTYPE of Apostemidium norvegicum (Gremmen No. 1296).

NOTES:

This species differs from $V$. sporogyra in the following respects. It has mostly simple paraphyses, no epithecium; the receptacle is rather smooth; the asci and spores are half as long; the apothecium remains firmly attached to the substrate after drying; and the perihymenial zone is not blued by iodine.

A specimen, described by Velenovský (12) as V. pezizoides var. calamaria, 
on deposit in the National Museum at Prague belongs in section Microstemium. It is very close to $V$. norvegica in various respects, especially in that its perihymenial zone is not blued by iodine, but differs from it in being much larger (apothecia $1.5 \mathrm{~mm}$. in diam.; apices of paraphyses 4 to $7 \mu$ wide). Since it has proved impossible to locate asci, and since only a few spores are present in the material available it seems best, at the present time, not to assign it to any particular species.

\section{EXCLUDED SPECIES}

1. Vibrissea aquatica Vel. Mon. Disc. Boh. 1: 383, 1934, = Mollisia sp.

2. Vibrissea microscopica B. \& Br. Ann. Mag. Nat. Hist. IV 17: 142, 1876, = ? Gorgoniceps or ? Scleroderris.

\section{SUMMARY}

A key, and detailed synonymies and descriptions of the five accepted species and four accepted forms of the sections Apostemium and Microstemium of the genus Vibrissea (Fungi, Inoperculate Discomycetes) are provided.

\section{RESUMEN}

Este trabajo presenta una clave, sinonimias y descripciones detalladas de las cinco especies y cuatro formas aceptadas por el autor, de las secciones A postemium y Microstemium del género Vibrissea (Hongos, Discomycetos Inoperculados).

\section{LITERATURE CITED}

1. Berkeley, M. J., and Broome, C. E., Notices of British fungi, Ann. Mag. Nat. Hist. III 18: 51-129, 1866.

2. Graddon, W. D., A guide to lignicolous species of Apostemidium, Trans. Brit. Mycol. Soc. 48: 639-46, 1965.

3. Gremmen, J., Nieuwe Vondsten van Discomyceten in Nederland, Fungus 24: 8-12, 1954.

4. Ingold, C. T., Aquatic Ascomycetes: Discomycetes from lakes, Trans. Brit. Mycol. Soc. 37: 1-18, 1954.

5. Karsten, P. A., Monographia Pezizarum fennicarum, Not. Sällsk. Fauna Flora Fenn. Förhl.10: 101-206, 1869.

6. Kjøller, A., Two finds of aquatic Discomycetes in Scandinavia, Bot. Tidssk. 56: 242-46, 1960.

7. Lanjouw, J. [ed.], International Code of Botanical Nomenclature, Regnum Veg. 23: 1-372, 1961.

8. Lanjouw, J., and Stafleu, F. A., Index Herbariorum, ed. 5, Regnum Veg. 81: 1-251, 1964.

9. Sánchez, A., and Korf, R. P., The genus Vibrissea, and the generic names Leptosporium, Apostemium, Apostemidium, Gorgoniceps and Ophiogloea, Mycologia 58: in press, 1966. 
10. Sauter, A. E., Beiträge zur Kenntnis der Pilzvegetation des Ober-Pinzgaues im Herzogthum, Flora 24: 305-20, 1841.

11. - - Beiträge zur Pilzflora des Pinzgaues, Mitt. Ges. Salzburg Landeskunde 6: 41$54,1866$.

12. Velenovský, J., Monographia discomycetum Bohemiae 1: 1-436; 2: pl. 1-31; published by the author, Prague, 1934. 